\title{
ESP COURSE DESIGN: AN INTEGRATED APPROACH
}

\author{
Sitti Nurpahmi \\ Fakultas Tarbiyah dan Keguruan UIN Alauddin Makassar \\ Kampus II: Jalan Sultan Alauddin Nomor 36 Samata-Gowa \\ Email: nurpahmi74@gmail.com
}

\begin{abstract}
:
ESP course design has grown to become one of the most prominent areas of EFL teaching since the early 1960's. It is a phenomenon that grew out of a number of covering trends. Nowadays there are many courses are offered in ESP areas. There has been several approaches in designing course but each of them has weakness and strengthens. This article aims at finding new approaches in ESP course design that integrate all the needs that the course. It integrates three component of need analysis, PSA, TSA, and LSA, and integrated source of data-stakeholder, learner, teacher, and expert. Each of the steps of integrated approach integrate all component needed.
\end{abstract}

\begin{abstract}
ABSTRAK:
ESP disain telah menjadi salah satu bidang yang paling menjadi pusat perhatian dalam pengajaran bahasa Inggris sebagai bahasa asing sejak awal 1960. Isu ini menjadi fenomena yang terus berkembang dan melahirkan berbagai kecenderungan. Dewasa ini ada banyak kursus yang ditawarkan dalam bidang ESP. Telah banyak pendekatan yang digunakan untuk mendisain kursus ESP namun menurut hemat penulis pendekatan-pendekatan tersebut memiliki kelemahan dan kelebihan. Artikel ini bertujuan untuk mengintegrasikan berbagai pendekatan untuk memenuhi semua kebutuhan dalam kursus ESP. Pendekatan ini akan mengingtegrasikan tiga komponenan analisis kebutuhan PSA, TSA dan LSA. Pendekatan ini juga akan mengintegrasikan sumber data yang dibutuhkan dalam menganalisis kebutuhan yakni dari stakeholders, pembelajar, guru, dan ahli. Setiap langkah dalam disainnya akan mengintegrasikan setiap komponen yang dibutuhkan.
\end{abstract}

\section{Keywords:}

English for Specific Purposes, course design, integrated approach

ENGLISH for Specific Purposes (ESP) course design has grown to become one of the most prominent areas of EFL teaching since the early 1960's. Hutchinson and Water ${ }^{1}$ states that ESP is not a planned and coherent movement, but rather a phenomenon that grew out of a number of covering tends.

Course design is a series activity to design course or learning activities. Hutchinson and Water ${ }^{2}$ define Course design is the process of interpreting the raw needs analysis data to produce "an integrated series of learning experiences to lead learners to a particular state of knowledge. While According to Munby, ${ }^{3}$ "ESP courses are determined in all essentials by the prior analysis of the communication needs of the learners".

Course design is a series process - need analysis, interpreting need analysis data, creating syllabus, material writing, classroom teaching, and evaluation. There are 
some approaches in ESP course design. Each of them has weakness and strengt. This article is to find out the new approach that integrate the positive point of each.

\section{ESP CHARACTERISTICS}

Strevens ${ }^{4}$ characterizes ESP course with absolute characteristics and variable characteristics. The absolute characteristics of ESP are:

1. Language teaching is designed to meet specified needs of the learner;

2. It is related in content to particular disciplines, occupation and activities;

3. It is centred on the language appropriate to those activities in syntax, lexis, discourse, semantics and so on, and analysis of the discourse

4. It is designed in contrast with General English.

Two variable characteristics of ESP are:

1. ESP may be restricted to the language skills to be learned, e.g. reading;

2. ESP may not be taught according to any pre-ordained methodology.

Robinson's ${ }^{5}$ gives two criteria of ESP course as follows:

1. ESP is normally 'goal-directed', and

2. ESP courses develop from a needs analysis which aim to specify what exactly it is that students have to do through the medium of English, and a number of characteristics which explain that ESP courses are generally constrained by a limited time period in which their objectives have to be achieved and are taught to adults in homogenous classes in terms of the work or specialist studies that the students are involved in.

Furthermore, Dudley-Evans and St John ${ }^{6}$ characterizes ESP course with absolute and variable characteristic. The following are those characteristics:

1. Absolute characteristics:

a. ESP is designed to meet specific needs of the learner;

b. ESP makes use of the underlying methodology and activities of the disciplines it serves; and

c. ESP is centred on the language (grammar, lexis, register), skills, discourse and genres appropriate to these activities.

2. Variable characteristics:

a. ESP may be related or designed for specific disciplines;

b. ESP may use, in specific teaching situations, a different methodology from that of general English;

c. ESP is likely to be designed for adult learners, either at a tertiary level institution or in a professional work situation; it could be used for learners at secondary school level;

d. ESP is generally designed for intermediate or advanced learners; and

e. Most ESP courses assume basic knowledge of the language system, but it can be used with beginners.

Based on the above quotations, ESP is the use of English for specific purposes based on the learners' need. The information of the learners' need got through the need analysis.

Moreover, Dudley-Evans and St John ${ }^{7}$ suggest some parameter to be considered 
in designing course as follows:

1. Should the course be intensive or extensive?

2. Should the learner's performance be assessed or non-assessed?

3. Should the course deal with immediate needs or with delayed needs?

4. Should the role of the teacher be that of the provide of knowledge and activities, or of a facilitator of activities arising from learners' expressed wants?

5 . Should the course have a broad or narrow focus?

6. Should the course be pre-study or pre-experience or non parallel with that study or experience?

7. Should the material be common-core or specific to learners' study or work?

8. Should the group taking the course be homogeneous or heterogeneous?

9. Should the course design be worked out by the language teacher after consultation with the learners and the institution, or should it be subject to a process of negotiation with the learners?

Robinson's ${ }^{8}$ states that the characteristics of ESP courses as follows:

1. First, ESP is goal directed - the learners are not learning the English language for the sake of it, but because they need, or will need, to use English in their professional or academic lives. EAP learners are usually current higher education students or members of staff or they are hoping to go on to higher education after their EAP course. They need to learn English in order to succeed in their academic careers.

2. Second, ESP courses are based on an analysis of needs, which aims to specify as closely as possible exactly what it is that the learners have to do through the medium of English. This means taking into account the opinions of all the various stakeholders. For an undergraduate student, this could mean the learner, his or her parents, and sponsors, present and future lecturers, examiners, administrators, materials writers etc. EAP, therefore, involves an attitude to learning and teaching that believes that it is possible and useful to specify what language and practices are required in a particular academic context and that it is worthwhile to focus teaching on this. For that reason, one important feature of EAP courses is the close attention that is paid to the learners' aims and what they are working on, studying or planning to study. The first stage in any EAP, and ESP, course, therefore, is to find out exactly why the learners are learning English and what language and practices they will need to pay attention to.

3. Often there is a very clearly specified period for the ESP course. Most EAP students are undertaking fixed term courses in preparation for a particular task - such as an essay, dissertation or conference presentation - or an academic course or they are studying English for a short time every week along with their academic courses or jobs.

4. ESP learners tend to be adults rather than children. Most EAP students are over 18 and they will either have made a difficult decision to study in an English medium university or, for example, researching, publishing or teaching in English may be a requirement.

5. Learners may need specialist language, but this is not necessarily so. It is the linguistic tasks - including language and practices - that the students will need to en- 
gage in that define the course. As with all ESP, an EAP lecturer would not take a text and ask, "What can I do with this text?" The starting point is always, "What do my learners have to do? What texts will they need to read? What will my students need to do with this text and how can we help them to do it?"

6. In some cases, a very high level of proficiency is not necessarily required, as long as the learners can succeed in their aims. Students, for example, need to be able to understand their lectures, fellow students and textbooks and obtain good marks for assignments and examinations. The role of the EAP lecturer is to find ways to enable them to do this - getting their present tenses correct may not be as important as understanding the overall structure of the report they have to write.

Based on the citation above it shows that Robinson's criteria to ESP course is goal oriented. According to him the learners are not learning the English language for the sake of it, but because they need, or will need, to use English in their professional or academic lives. EAP learners are usually current higher education students or members of staff or they are hoping to go on to higher education after their EAP course. They need to learn English in order to succeed in their academic careers.

While According Widdowson ${ }^{9}$ ESP course design must be process oriented. A process oriented approach in designing ESP course based on the principle to satisfy the cognitive need of the learners, guarantee the eventual attainment of desired terminal behavior. A process oriented approach based on subject methodologies contains because these needs converge in learning process itself.

\section{FACTORS AFFECTING ESP COURSE DESIGN}

In relation to the factors affecting course design Hutchinson and Water ${ }^{10}$ used Kipling's honest serving men to outline the basic questions that we need to know before designing course, as follows:

1. Why does the students need to learn?

2. Who is going to be involved in the process? This will need to cover not just the students, but all the people who may affect on the process: teachers, sponsors, inspectors, etc.

3. Where is the learning to take place? What potential does the place provide? What limitation does it impose?

4. When does the learning take place? How much time is available? How will it distributed?

5. What does the student need to learn? What aspect of language will be needed and how will they be described? What level of proficiency must be achieved? What topic areas will need to be covered?

6. How will the learning be achieved? What learning theory will underlie the course? What kind of methodology will be employed?

Based on the question, Hutchinson and Water ${ }^{11}$ identified factors affecting to

ESP course design namely language description, theories of learning and need analysis, as can be seen in the following figure: 


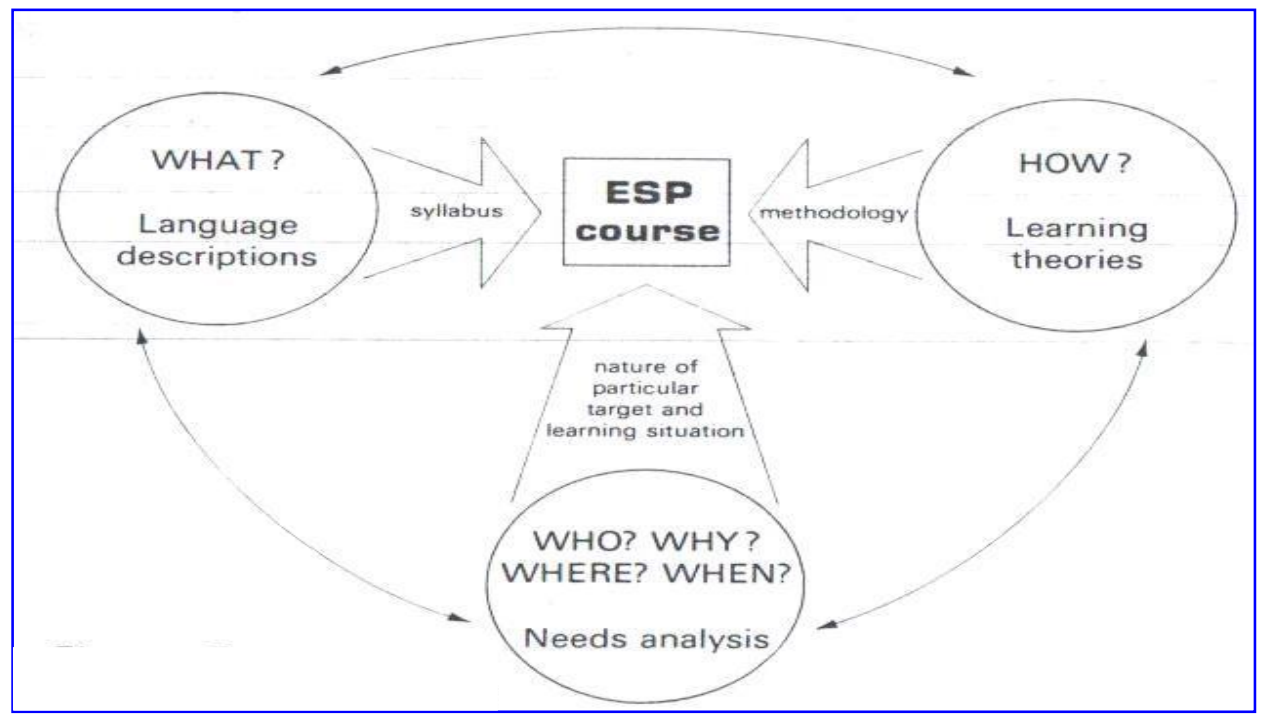

Figure 1 Factors affecting ESP Course Design

The above figure shows that there are three main points affecting ESP course design. The first is language descriptions, the answer of question of what. Language description shows the language knowledge needed by the learners that put at the syllabus. The second factor is how the learner learn a language, and the third factor is the nature of particular target and learning situation.

Phillips (as citied in Wello and Dollah) ${ }^{12}$ considers factors contributing to the success and failure of ESP course as follows:

1. The subject content embodied in the learners' purposes;

2. The duration for ESP course

3. The weekly intensity of the course

4. The composition of the students group according to their mother tongues

5. Age, academic background, degree of competence in second language (if any)

6. The staff- students ratio

7. The staff teaching load

8. The organizational structure of educational institution

9. The budgetary provision for the course and

10. The availability of educational technology.

Furthermore, Wello and Dollah ${ }^{13}$ classified factors affecting the ESP course into institutional - time allotted for learning English, classroom and learning condition, and attitude of the head institution and staff--, the teachers factor - the competence of the teacher, the confidence of the teachers in using English, teaching strategies, the attitude of the teacher--, and the learner factor - internal and external factors.

\section{APPROACHES IN ESP COURSE}

An approach is a set of correlative assumptions dealing with the nature of language teaching and learning. An approach is axiomatic. It describes the nature of 
the subject matter to be taught. ${ }^{14}$ There are many different approaches to ESP course design. Those approaches are explained as follows:

1. Language-centred course design

Hutchison and Waters ${ }^{15}$ states that Language-centred course design approachis the simplest kind of course design process and one most familiar to English teachers. It aims to draw as direct a connection as possible between the analysis of the target situation and the content of the ESP course. It proceeds as follows:

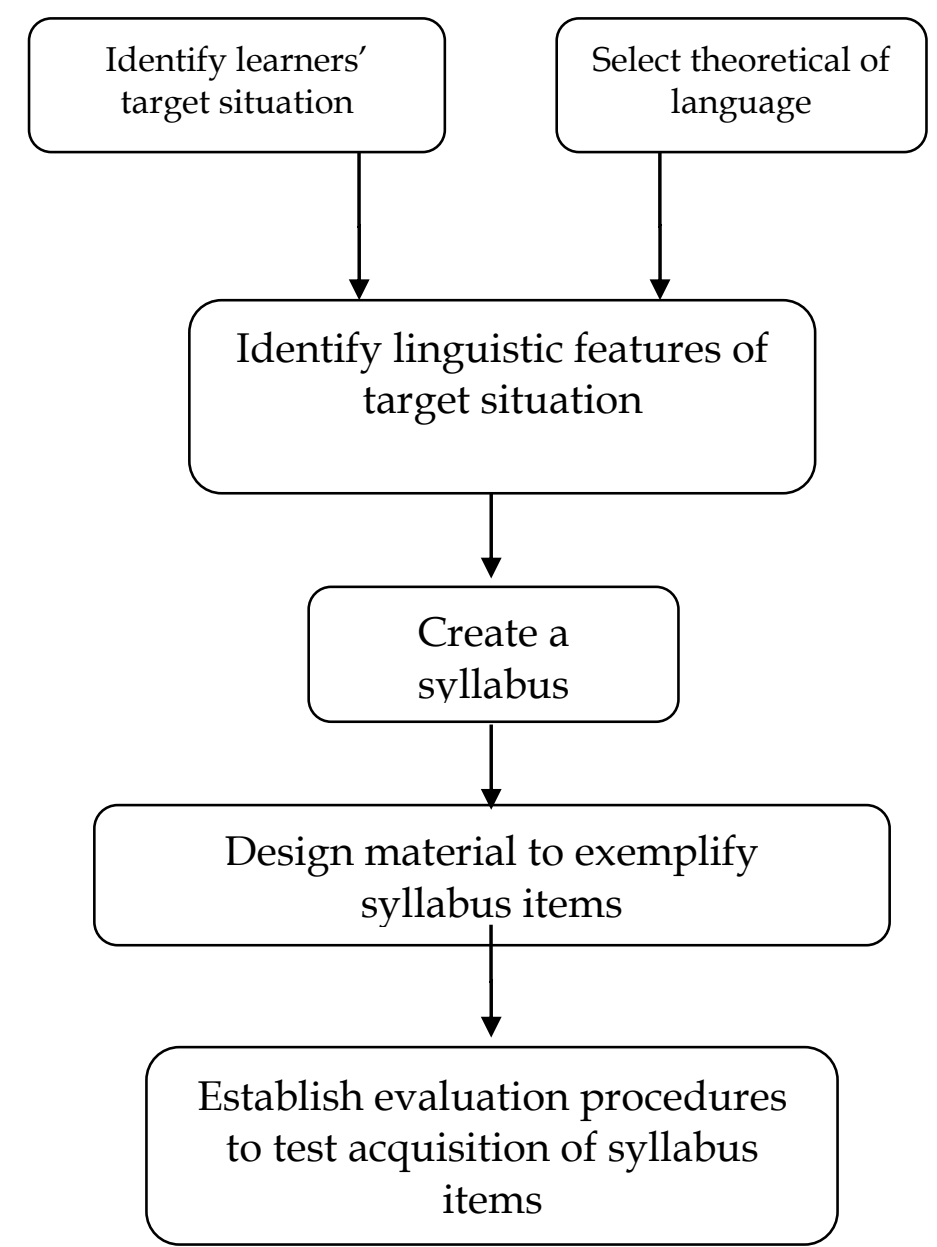

Figure 2. A language centered approach to course design

The figure above shows that this approach starts at identifying learner's target situation and then select theoretical language to identify the linguistic features that the learners need. Based on the identified data, syllabus created. The next step is designing material based on the syllabus, then establishing evaluation to see the successfulness of the course.

\section{Skills-centred course design}

Skills-centred course design is a reaction both to the idea of specific registers of English as a basis for ESP and to the practical constraints on learning imposed by limited time and resources. Its aim is not to provide a specified corpus of linguistic know- 
ledge but to make the learners into better processors of information. ${ }^{16}$

The process of the approach as follows:

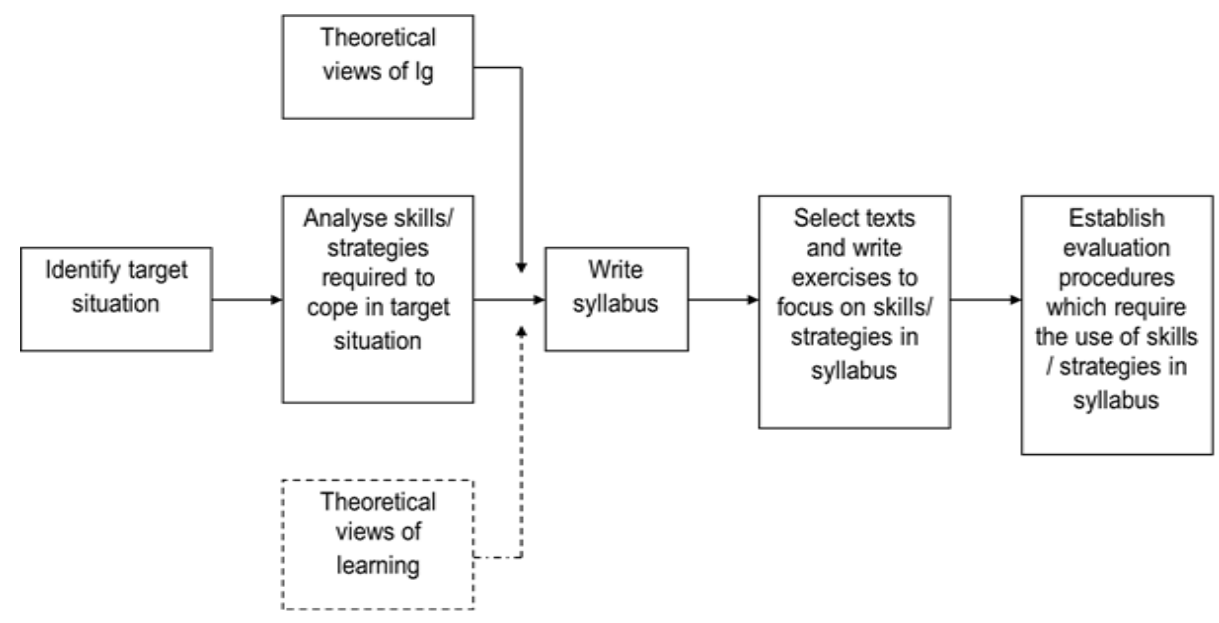

Figure 3. Skill centred approach

Skill centred approach starts at identifying target situation. Based on the data from target situation analysis, it is determined theoretical views of language, skill required to cope target situation, and theoretical view of learning. Based on all data the syllabus is created. Based on the syllabus, then material is developed and then conducting evaluation.

3. Learner-centred approach

It is based on the principle that learning is totally determined by the learner even though teachers can influence what is taught but what the learners learn is determined by the learner alone. Learning is seen as a process in which the learners what knowledge or skill they have in order to make sense of the flow of new information. Learning therefore, is an internal process, which is crucially dependent upon the knowledge the learners already have and their ability and motivation to use it. The following is the process in Learner centred model: 17

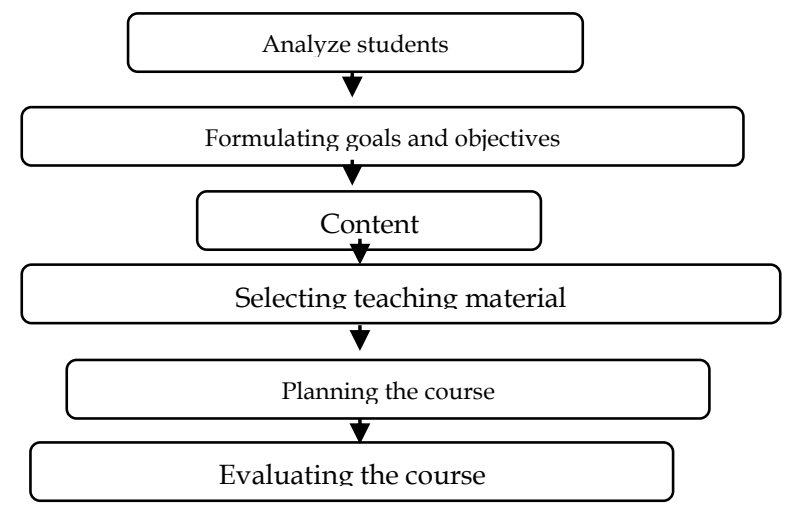

Figure 4. A learner-centered approach to course design 


\section{Learning-centred approach}

The term learning-centred approach introduced by Hutchison and Waters. ${ }^{18}$ It is seen as a process in which the learner use what knowledge or skills they have to make sense of the flow of new information. It is an internal process, which is crucially dependent upon the knowledge the learner already have and their ability and motivation to use it. It is a process of negotiation between individuals and the society. Society sets the target and the individuals must do their best to get as close to that target as is possible.

This approach has two implications:

a. Course design is a negotiated process. The ESP learning situation and the target situation will both influence the nature of the syllabus, materials, methodology and evaluation procedures.

b. Course design is a dynamic process. It does not move in a linear fashion. Needs and resources vary with time. The course design, therefore, needs to have builtin feedback channels to enable the course to respond to developments.

If we took a learning-centred approach, we would need to ask further questions and consider other factors, before determining the content and methodology of the course:

a. What skills are necessary to be taught?

b. What are the implications for methodology of having a mono-skill focus?

c. How will the students react to doing tasks involving other skills?

d. Do the resources in the classroom allow the use of other skills?

e. How will the learners react to discussing things in the mother tongue?

f. How will the students' attitudes vary through the course? Will they feel motivated?

g. How do students feel about reading as an activity?

The important point is that these questions must be asked and the results allowed to influence the course design. The learning-centred course design process is shown in this diagram:

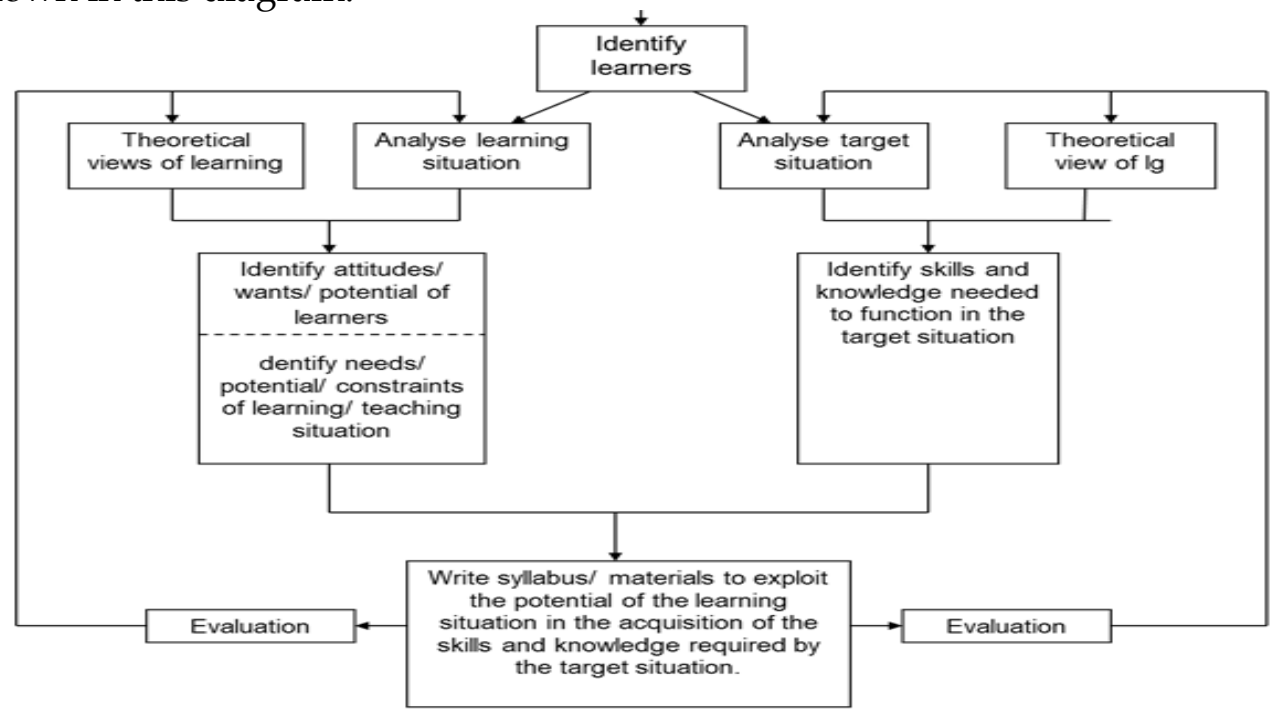

Figure 5.Learning Centered approach 


\section{INTEGRATED APPROACH}

Integrated Approach is an approach that integrate teacher centred learning, learner centred leaning and learning centred approach. It is based on the principle that learner in learning process must be guided by the teachers to learn optimally. Not all the learning source comes from the learner, but the learning process can be processed optimally if the all components of the learning process function well.

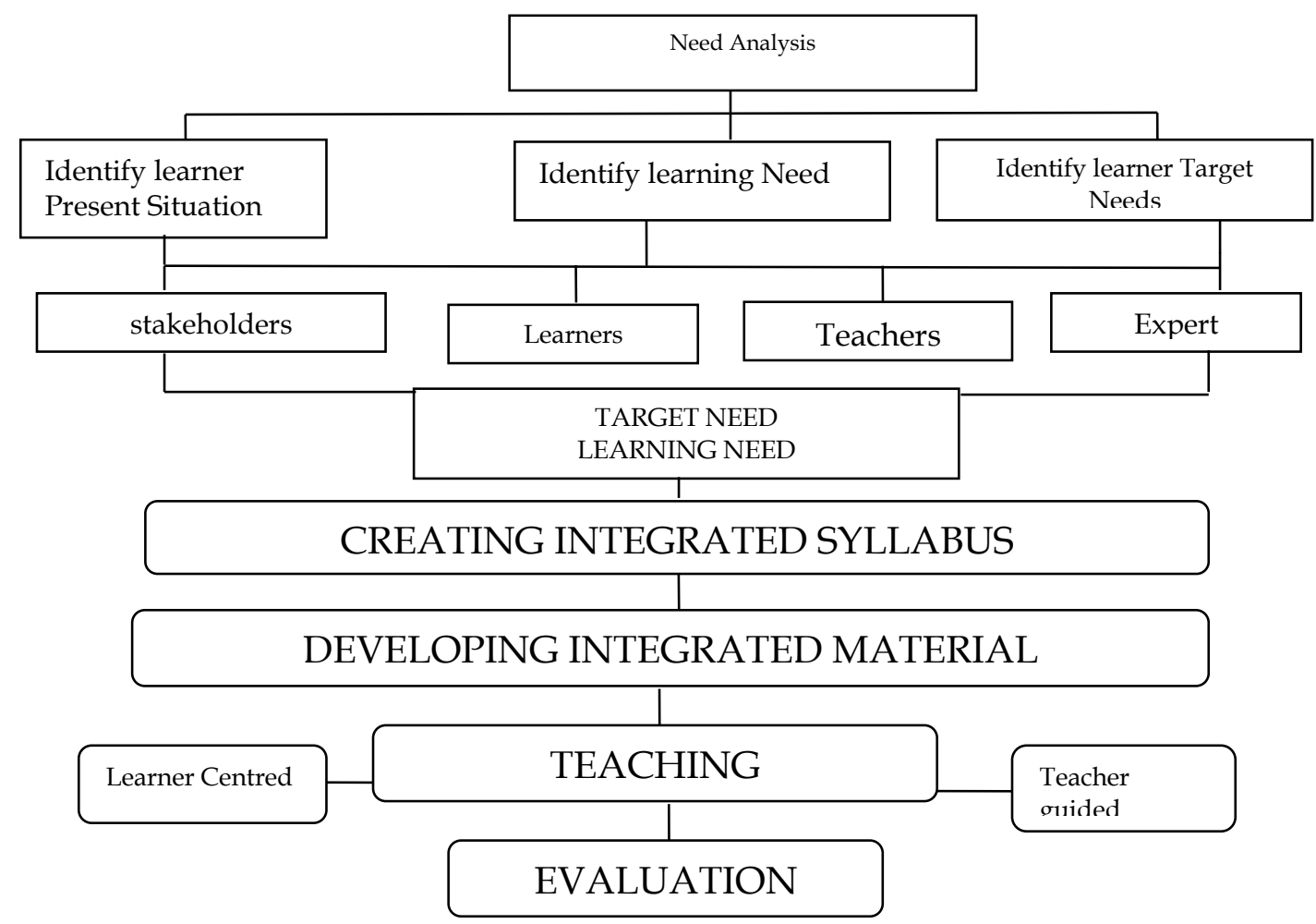

Figure 6. Integrated approach

Integrated approach in need analysis means integrate three component of need analysis, PSA, TSA, and LSA, which are involved integrated source of datastakeholder, learner, teacher, and expert. labus.

The next step is creating syllabus which integrate more than two kinds of syl-

The third step in course design is material development. In this step, course designer integrate content material and functional language.

Teaching ESP must integrate students centred and teacher guided. In teaching process the main factor determining the failure or successfulness are learners and teachers. The teachers is nor the only source of the material, but teacher plays key role to facilitate learners to learn.

Evaluation is a final part in course design. In order the information gathered maximum so the method of collecting data for evaluation must also be integrated, 


\section{ENDNOTE}

1. T. Hutchinson, and A. Waters, English for Specific Purposes: A learning-centred Approach. Cambridge: Cambridge University Press, 1987, p. 6-8.

2. Ibid, p. 65

3. J. Munby, Communicative Syllabus Design, Cambridge: Cambridge University Press, 1987, p. 2.

4. P. Strevens, ESP after twenty years: A re-appraisal, In M. Tickoo (Ed.), ESP: State of the art (113), SEAMEO Regional Language Centre, 1988.

5. P. Robinson, ESP (English for Specific Purposes), Pergamon, 1980.

6. T. Dudley-Evans, and M. J. St. John, Developments in English for Specific Purposes, Cambridge: Cambridge University Press, 1998.

7. Ibid, p. 145

8. Robinson, loc.cit., p. 2-5.

9. H. G. Widdowsen, English for Specific Purposes: Criteria for course design for English for academic and technical purposes, Newbury House, 1981, p. 102.

10. Huncthinson and Waters, loc.cit., p. 21-22.

11. Ibid., p. 24.

12. Well and Syarifuddin, An Introduction to English for Specific Purposes, UNM University Press, 2008, p. 34.

13. Ibid., p. 97

14. Jack C. Richard, Communicative Language Teaching Today, Cambridge University Press, 2006.

15. Huncthinson and Waters, loc.cit., p. 65-66.

16. Huncthinson and Waters, ibid., p. 65-66.

17. P. Sysoyev, Developing an English for Specific Purposes Course Using a Learner Centered Approach: A Russian Experience, The Internet TESL Journal, Vol. VI, No.3, March 2000 http://iteslj.org/, 2006.

18. Hutchinson and Waters, op.cit, p. 72.

\section{REFERENCES}

Dudley-Evans, T., and M. J. St. John, Developments in English for Specific Purposes, Cambridge: Cambridge University Press, 1998.

Hutchinson, T., and A. Waters, English for Specific Purposes: A learning-centred Approach, Cambridge: Cambridge University Press, 1987.

Harmer, Jeremy, The Practice of English Language Teaching, London: Longman, 1991.

Munby, J., Communicative Syllabus Design, Cambridge: Cambridge University Press, 1987.

Richard, Jack C., Communicative Language Teaching Today, Cambridge University Press, 2006.

Robinson, P., ESP (English for Specific Purposes), Pergamon, 1980.

Strevens, P., ESP after twenty years: A re-appraisal, In M. Tickoo (Ed.), ESP: State of the art (1-13). SEAMEO Regional Language Centre, 1988.

Sysoyev, P., Developing an English for Specific Purposes Course Using a Learner Centered Approach: A Russian Experience, The Internet TESL Journal, Vol. VI, No.3, March 2000 http://iteslj.org/, 2000.

Widdowsen, H. G., English for Specific Purposes: Criteria for course design for English for academic and technical purposes, Newbury House, 1981. 